\title{
DWELLING IN AN ECOLOGICAL SUBSTRATE Landscape based strategies for flood adaptation in the Sabana de Bogotá
}

\author{
Autor: Claudia Lucia Rojas Bernal \\ University of Leuven. Department of Architecture. OSA Research Group Urbanism \& Architecture \\ Directores: Bruno De Meulder y Kelly Shannon \\ Email: claudialucia.rojasbernal@asro.kuleuven.be
}

\section{RESUMEN}

La Sabana de Bogotá afronta el conflicto creciente entre el desarrollo urbano y un sistema de manejo de agua ineficiente. Ante esta contradicción, la investigación estudia cómo se pueden modificar las relaciones conflictivas entre la vivienda dirigida a sectores de bajos ingresos y el medio ambiente para crear una interacción constructiva. La necesidad incuestionable de construir vivienda social puede ser vista como un riesgo para el manejo sostenible de agua, pero también como una oportunidad única para proponer intervenciones espaciales estratégicas. El artículo presenta la investigación y diseño de dos secciones que atraviesan el Río Bogotá y están expuestas a la presión de desarrollo urbano. En cada sección, el diseño interviene el sistema hídrico para que resuelva problemas cuantitativos y cualitativos del agua y al mismo tiempo genere la estructura para nuevos tejidos de vivienda. La tesis tiene tres objetivos. Primero, presentar una aproximación crítica a las tendencias actuales de urbanización. Segundo, cuestionar los modelos de planeamiento actual basados en la distinción entre las áreas rurales y urbanas y el abandono de la conservación ambiental en el ámbito urbano. Finalmente, desarrollar nuevas tipologías urbanas que integren el manejo sostenible de agua. La hipótesis de la investigación es que, a través del diseño del sistema hídrico, las inversiones privadas y públicas se pueden dirigir para crear una estructura urbana pública, sostenible y resiliente a largo plazo.

Palabras clave: gestión del agua, vivienda social, Bogotá, urbanismo del agua

\begin{abstract}
The Sabana de Bogotá is facing a continuously increasing conflict between urban development and a saturated water management system. The research investigates how current contested relations between lowincome housing and environmental stress can be converted into a constructive interplay. The unquestionable necessity of building new social housing can be seen as a major threat for sustainable water management but also as a unique opportunity to propose strategic spatial interventions. This paper present design investigations in two sections that cut across the Bogotá River and are undergoing development pressure. In each site the design proposes a water structure that solve qualitative and quantitative water issues while delivers a framework for new housing fabrics. The thesis has three objectives. First, to develop a critical approach to current development trends and to envision alternative development schemes for the region. Second, to challenge the current planning models based on the distinction of "urban" and "rural" areas and the abandonment of environmental conservation in the urban sphere. Finally, to develop new urban typologies that integrate sustainable water management. By designing the water system, public and private investment can be oriented towards a sustainable and resilience public structure in the long term.
\end{abstract}

Keywords: sustainable water management, low-income housing, Bogotá, water urbanism 


\section{THE HOUSING PROBLEM}

\subsection{Large scale challenge}

Bogotá's population increased ten times between 1951 and 2005. Housing stock has increased twenty-two times during the same period. This large housing production allowed to decrease the number of inhabitants per house (from 8,43 in 1951 to 3,99 in 2005) alleviating overcrowding rates. However, the housing production has been unable to cover both the qualitative and the quantitative deficit (Metrovivienda, 2011). In 2014, the total housing deficit for the Bogotá was calculated in 221,857 dwelling units (87,767 new dwellings and 134,090 dwellings that need improvement) (Secretaria del Habitat, 2015). In the municipalities close to Bogotá (Mosquera, Funza, Chía, Cota and Soacha) the housing deficit was calculated in 52,694 dwelling units (29,782 new dwellings and 22,912 dwellings that need improvement) (DANE, 2006).

Bogotá's current population growth has reached a stabilization phase that is reflected in a yearly average of $2 \%$. This means that each year there are 51,000 new families in Bogotá of which 21,000 use the formal market to solve their housing needs. The rest depend on renting, self-construction or co-housing with a familiar. (Torres, 2012). This rate is incremented by internal displacement. Between 1985 and 2008, 709,875 displaced persons arrived to Bogotá, (10\% of current Bogotá population) mainly to informal origin neighborhoods in the poor peripheries (CODHES, 2008).

In Bogotá, the informal market has played a pivotal role in the provision of land for low-income housing. However, "illegal development rarely took the form of land invasions. Rather, 'pirate' developers sub-divided land at the edge of the city, sold it without planning permission and offered settlers a minimal supply of infrastructure" (Gilbert, 2009:427). Low-income population built their homes through 'self-help' construction. Informal areas have been also intensely densified which decreases the quantitative deficit but hardly decreases of the qualitative deficit.

The availability of cheap and well located land is one of the major obstacles for the production of low-income housing. Since the mid-twenty-century, the traditional agricultural lands that surrounded the city became object of speculation. Sustained population and economic growth fueled rises in urban land prices. Different legislation attempts tried to control this phenomenon of land speculation but only until the end of the 90 s the Ley de Ordenamiento Territorial was implemented (Ley 388 de 1997). One of the aims was to control land prices, however, when it was implemented the prices already have significantly increased.

The large scale of the social housing issue makes for any government almost impossible to find a comprehensive solution. Public policy constrains to provide adequate housing are related with the high rate of poverty which make difficult to fulfill the conditions for access to subsidies or funding systems. The state has also a limited capacity of production even if it is through private partnerships. It also makes evident the need to develop a vision for the city and the region. The main question that this vision should address is: where to accommodate this new housing? That means, where and how the city will grow?

\subsection{A changing response}

Bogotá's response to these questions have been the creation of Metrovivienda in 1999 and the definition of an urban plan POT-2000. Metrovivienda was created in 1999. Originally it operates as public land bank agency. It provides serviced land on which private builders construct legal and affordable housing to counter informality and increase dwelling quality (Gilbert, 2009). Metrovivienda represents an exceptional case as an attempt to guaranty cheap land for low-income population. Public land banks were a widespread state response in the 1950s and 1960s. "The essential aim of a land bank is to appropriate some of the capital gain that private landowners and building developers derive from transforming rural into urban land" (Gilbert, 2009: 426). However, during the last fifty years, public land banks virtually disappeared and its effectiveness has been seriously criticized, especially in developing countries (Gilbert, 2009).

In 2000, the urban plan POT-2000 defined large expansion zones for low-income housing. Metrovivienda started to acquire the land. This process was slowly implemented because some of the plots had problems regarding legal property titles. The efficacy of the procedure also depends on the number of land owners with whom Metrovivienda should negotiate the land. The selection of land location was controversial. Historically it has been cheaper to build social housing in the peripheral lands. Soils quality and accessibility to infrastructure and services determine land prices and also explain Bogotá's patterns of growth. To effectively create a bank land Metrovivienda opted to buy large plots of land which were located in Bogotá's River floodplain. After 
several studies, Metrovivienda identified the areas that met the necessary conditions: cheap land prices, large plots and a small number of owners (Metrovivienda, 2011). El Recreo and El Porvenir, were selected to be developed the first large social housing projects.

During the administration of Gustavo Petro (2012-1026) the approach of Metrovivienda shift towards the promotion of social housing in the "extended center" establishing projects in association with local land owners. To achieve this goal, it promoted the use of service land within the existing built-up area. In 2015 Peñalosa was reelected as Bogotá's major. The current approach of Metrovivienda aims to recover its original function as bank land. The new administration argues that the projects developed during the previous administration had high costs and produced few dwelling units. The new aim of the institution is to provide 80.000 dwelling units in land on which the previous administration did not built due to environmental risks (El Tiempo, 2016).

The restrictions of land and policies in Bogotá has displaced social housing production to surrounding municipalities. In this municipalities urbanization rate has accelerated during the last decades as a direct consequence of the exhaustion of open and cheap land within the Bogotá administrative perimeter. For instance, between 1993 and 2005 the annual growth rate of Mosquera was 8.1\%, 2.92\% in Funza and 1.95\% in Bogotá, which is a clear indication of their development speed. (Secretaria Distrital de Planeacion, 2009).

The new vision of Peñalosa also includes new housing in the long term for 3 million people by 2050 , for which 15,000 hectares of land will be needed. The project, that comprises different areas of Bogotá, Soacha and Mosquera, has been called "Ciudad Paz". This ambitious plan includes areas with ecological value, for instance the protected area "Reserva Thomas Van Der Hammen", the river banks of the Bogotá River (Ciudad Rio), along of which the major's proposes the construction of a concrete pier and high rise buildings, and part of the irrigation district of Mosquera. These projects will possibly be part of a new Bogotá's POT currently under development. However, this approach raises serious concerns about its interplay with sensitive environments.
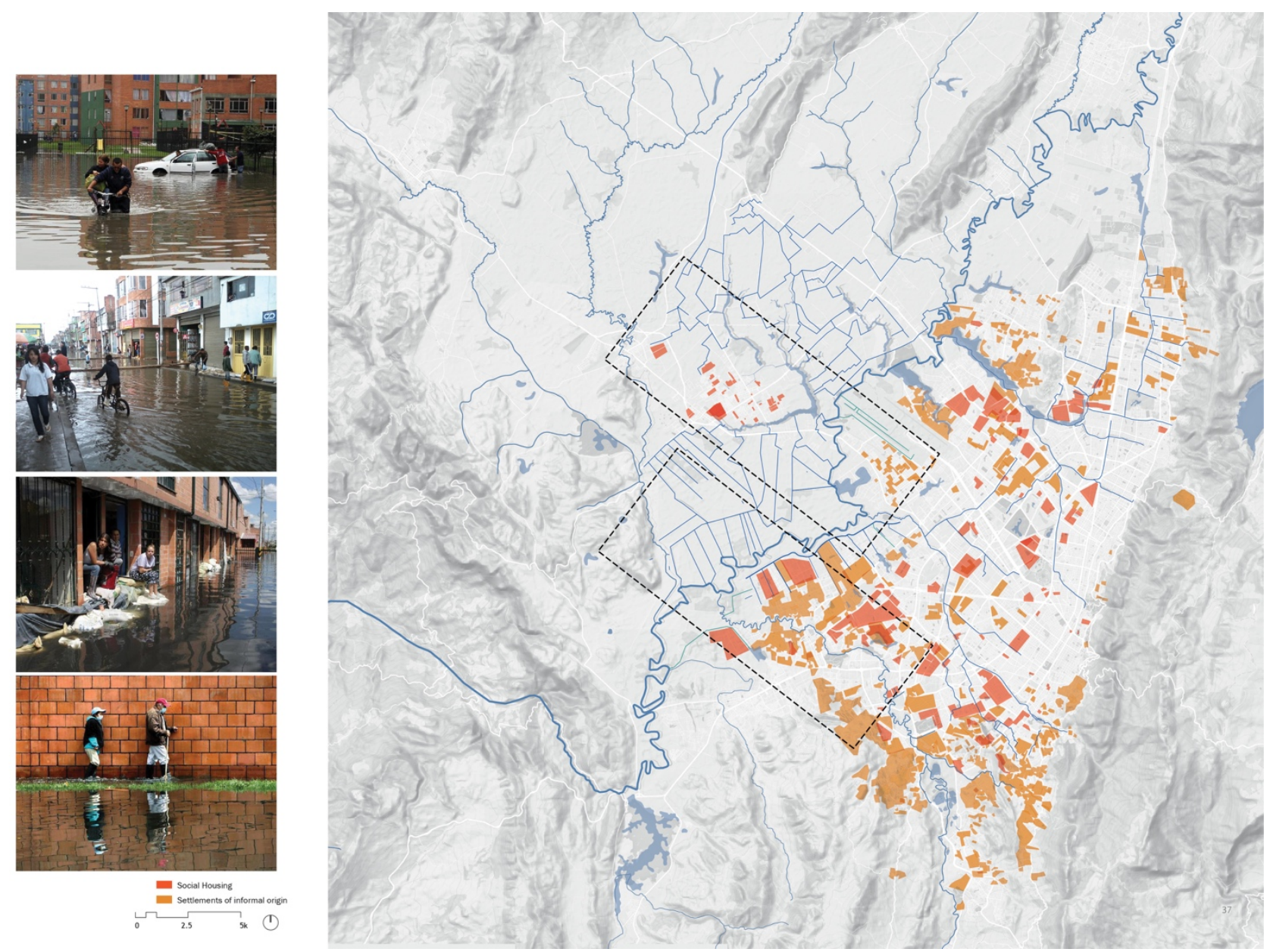

Fig. 1. Low income housing in the Sabana de Bogotá and its relation to the water system 2015 Elaborated by the author. 


\subsection{A regional and ecological approach}

The approach to housing problems in Bogotá focus mainly in measurable indicators of the missing amount of dwellings in relation to the number of families. This approach is based on the concept of deficit that was introduced in Colombia with modern planning by the Lebret mission in 1950 (Tarchopulos, 2003). Given the scale of the housing problem there is a need for an approach that overcome the simply quantification of the problem but also that is ecologically informed, and create qualitative environments. Water is the main critical element of this approach. Regarding the relation between settlements and the Bogotá River (the main landscape of the region), at the regional scale, there are three possible scenarios for development:

(a) A radical approach: To recover the natural conditions of the river, re-naturalize the river course and reclaim the natural floodplain. This would require the resettlement of around 1 million persons that lived in flood-risk areas, which is not economically, socially of logistically feasible.

(b) A traditional approach: To increase the river control through traditional hard engineered practices (heighten dikes and constructing new upstream dams). However, hard engineered practices already have been proved to be inefficient to control the complexity of dynamic systems (Novotny, 2008). Furthermore, it is already recognized that control engineering strategies need to be replaced by "more flexible, adaptive approaches to managing human activities and designing within the systems that sustain us" (Reed \& Lister, 2014).

(c) An alternative approach: To live with water by developing new urban patterns that work with the logics of landscape, reclaiming the river floodplain whenever is possible and protecting existing settlements. In the context of the Sabana de Bogotá, this landscape urbanism approach, understood as "working with, rather than against, the forces of nature" (De Meulder \& Shannon, 2010) offers a "framework of mediation and assemblage" (Hight, 2014) which can be the basis for a hybrid approach able to negotiate the challenges of the existing conflicts between any development (urban, agriculture, flower production or any or kind) with the (saturated) water management system.

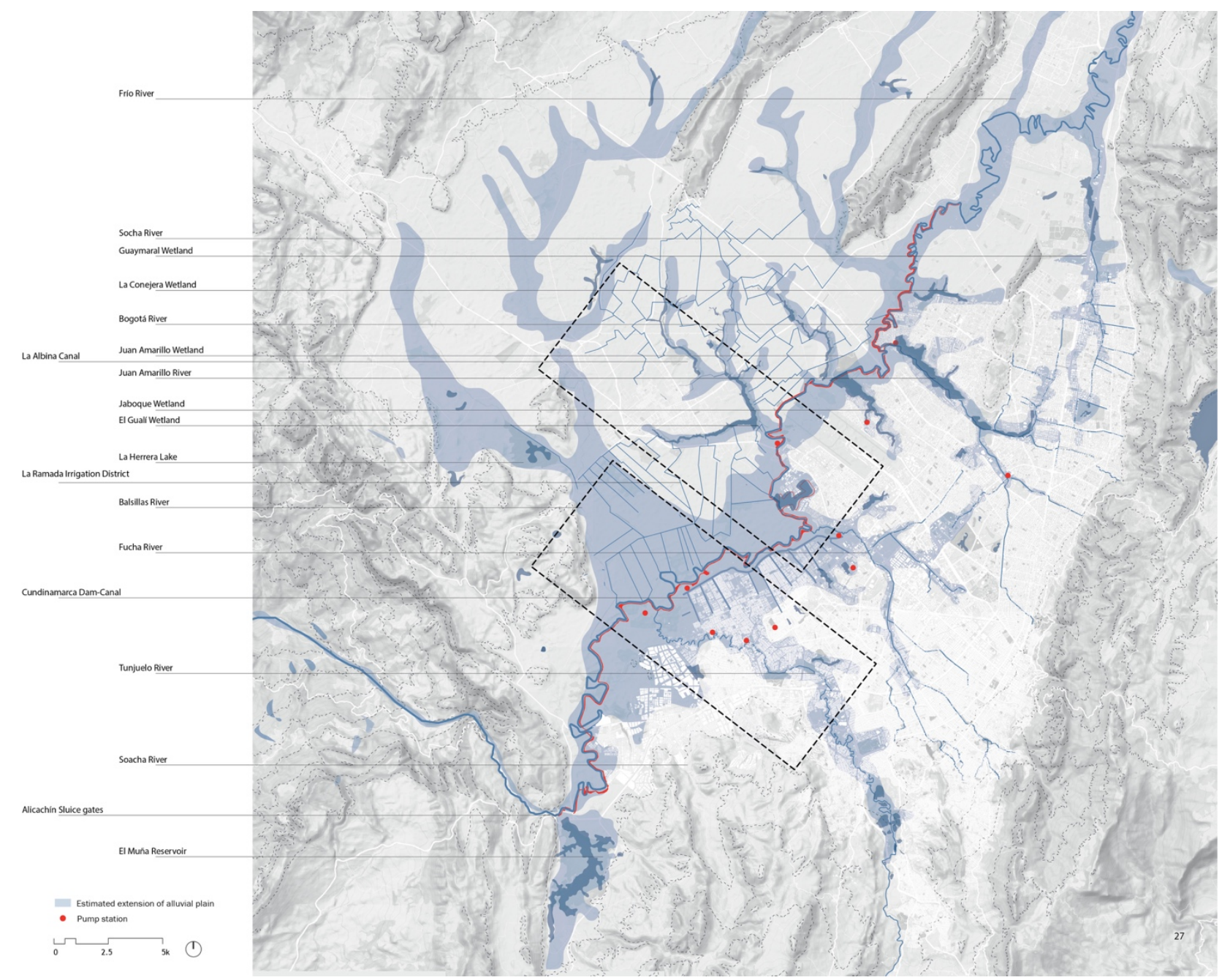

Fig. 2. Water system 2015

Elaborated by the author. 


\section{DESIGN INVESTIGATIONS IN TWO SELECTED SECTIONS}

Finding novel ways of tackling the rapid transformations of the periphery requires to replace the urban/rural dichotomy by the notion of a hybrid urban countryside or rural metropolis (Shannon, 2004). The maintenance of the agricultural land is crucial in terms of food security, water management and climate change adaptation. But how the growth of the city can be redirected to create these hybrid assemblages? The existing urban plans restrict development to normative and artificial boundaries that are in contradiction with the urban dynamics and landscape potentials. While there is certain capacity for re-densification within the existing tissue, it is limited to the voids in the urban fabric and restricted by the architectural structure of the low-income housing typologies.

Two sections across the Bogotá River were selected as a cross-scalar tool to read and interpret the territory. These two sections serve also as a projective tool to test spatial possibilities in each particular context. The aim of the research by design is not solve problems per se, rather "questioning-reformulating problems, forming insights, staging scenarios, and spatially intervening to simultaneously accept global forces while producing local values" (Shannon, 2016). The design is based on a previous descriptive analysis based on fieldwork and mapping. Detailed information about each section was collected during three fieldwork visits, AugustSeptember 2013, April-May 2014 and July-September 2014. The fieldwork documented settlement patterns, uses and activities in selected areas through photography, sketches and interviews. It provides an overview of the urban development trends and spatial water issues. Information about urban development plans and housing projects was collected in the planning offices of Funza, Mosquera and Bogotá. The collected information was processed through an interpretative mapping exercise. Mapping is used as a preliminary stage for the development of the design and to gain a deeper understanding of a specific context. "Interpretative mapping is a first step to transform a territory. An understanding of the context and the reading of sites - from diachronic and synchronic perspectives are necessary in order to create modifications that have logic and relate to the particularities of places and situations" (Shannon, 2008: 105). "Mapping is perhaps the most formative and creative act of any design process, first disclosing and then staging the conditions for the emergence of new realities" (Corner, 1999: 216).

After the descriptive phase, the research was developed through research by design (Prominski, 2016). A first approach to the cross-scalar design strategies was develop in an international design workshop and through 3 master thesis. These exercises generate a base that was further developed in this research. The sections are located at strategic points where the ongoing dynamics of low-income housing production collide with fragile environments and the same time are exposed to forceful environment risks. These fragile environments sometimes are only boundaries defined by planning regulations but disconnected from the ecological dynamics. On the other hand, the existing proposals for low-income housing are simply the definition of generic urban blocks and defensive measures against floods unrelated to specific landscape conditions. Therefore, design can explore the latent ecological potential of the sites and how urban form can be shaped by the landscape.

A previous analysis at the Sabana scale allowed to define a preliminary series of strategies and aims that were further explore at the urban scale in the selected sections. According to existing legislation, expansion areas should develop a partial plan (plan parcial). Land owners have to make an agreement and the public sector is involved in the definition and implementation of the master plan. Therefore, it is possible and feasible to proposed new alternatives that can balance the housing and environmental needs. The aim is not to provide a fix final solution but rather to highlight different strategies that can be used to adapt and live with floods. The main objectives of the present design investigations are:

(a) Recover the sponge condition of the floodplain, increasing resilience and biodiversity in the ecosystem (b) Increase the protection of existing settlements and create new settlements typologies that can adapt to variable water conditions.

(c) Reduce the dependence and the impact on external ecosystems (water supply from páramos, depletion of aquifers, water pollution in the Bogotá River)

Three strategic sites of intervention were selected within the two sections: the confluence of the Bogotá and Tunjuelo Rivers in the section I (Bosa) and Vereda Siete Trojes and Vereda EI Hato in the section II (Funza and Mosquera). These sites have the potential to create "ambiguous and rich thresholds that redefine the between urban/rural and between urban/nature" (Shannon, 2004). 


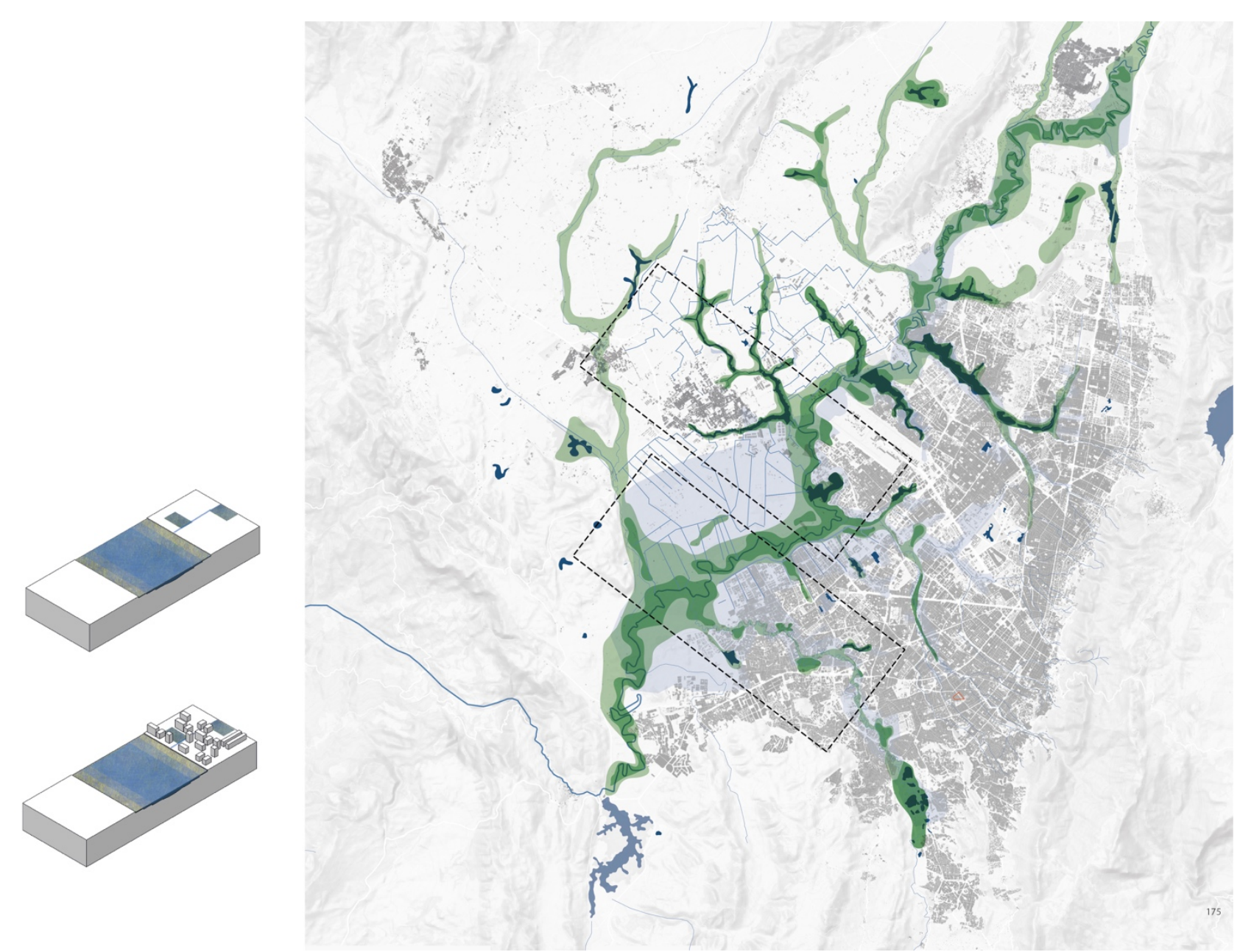

Fig. 3. Design investigation at the regional scale. Reconstructed wetlands and reclaiming the floodplain. Elaborated by the author.

\subsection{Design strategies}

The design strategies are not only drawn upon notions of sustainable water management but also upon the exiting logics of landscape and urbanization. These strategies condense a series of operations that lay at the intersection between redirecting natural processes and settling a terrain on which development can occur. The application of these strategies varies according to the careful reading of the potentials (landscape, economic and social) and threads of each site.

(a) Settling waters:

Different design research exercises proposed the used of topographical manipulations as a way to create a basic "printing plate" on which to anchor future development (Shannon, 2004; Palmboom, 2010; Shannon \& De Meulder, 2013; Nolf \& De Meulder, 2013). The importance of topographical manipulation was already understood by the pre-Hispanic culture that inhabited the wetlands (Rojas; De Meulder \& Shannon, 2015), these could be considered as archetypes of landscape urbanism (Shannon \& Manawadu, 2007). The different levels, created by modifying the natural terrain, can define places to hold, circulate, clean or harvest water (maintaining a cut and fill balance). This re-profiling the terrain creates a base layer that changes according to the weather conditions. In this way, the terrain can work as a sponge recovering the original condition of the Sabana de Bogotá. The variable conditions in the different levels can accommodate different programs and create habitats for endangered species. For instance, temporary flooded areas can be used for agriculture or recreation purposes and wetland ecosystems can easily flourish in permanently flooded areas. At the same time, the topographical manipulations define "safe levels" for housing and infrastructure.

\section{(b) Reconfiguring plots}

The re-configuration of plots intends to facilitate the implementation of the project as well as to preserve the landscape elements that defines the plots limits such us canals and trees. The design proposal is framed within this man-made nature: the grid of the plots. The grid serves as a framework but the design is not completely 
restricted by it. The geometry of the proposal is also informed by the natural process. The selected sites have the advantage of being divided in large plots, which will reduce the negotiation process with the stake-holders. According to existing legislation, to urbanize expansion areas it is necessary to develop a partial plan (plan parcial). Land owners have to make an agreement and the public sector is involved in the definition and implementation of the master plan. Therefore, it is possible and feasible to propose new alternatives that can balance the housing and environmental needs. Working with the grid of the plots also allows to developed the project by phases, according to the way in which land becomes available.

(c) Intersecting landscape and settlements

Settling with waters not only attempts to cope with water issues in terms of quantity, but also to create a hydrological infrastructure that allows new interplays between housing and productive landscapes. This infrastructure has three functions. (1) To make visible the flows of water creating general awareness about the water crisis. Although it is difficult to resurrect the symbolic meaning of water, the magnitude of the crisis calls for establishing new sociocultural relations with water (Shannon, 2013). A first step towards this goal is to bring back water to the public sphere. (2) To close the water cycle by harvesting and recycling water on site. (3) To integrate biological diversity and socio-cultural uses by designing "polytechnic" water infrastructure.
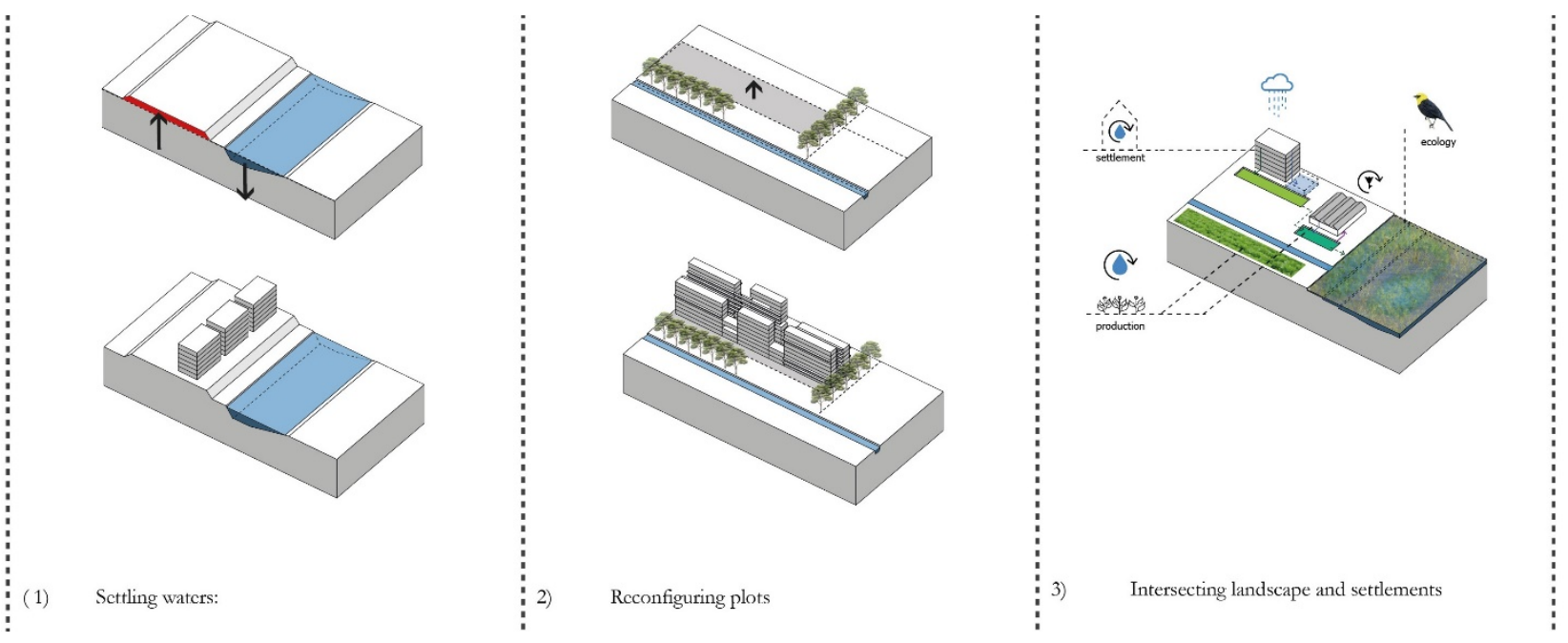

\section{SECTION I. BOSA}

The confluence of the Bogotá and Tunjuelo Rivers is one of the few areas with vacant land within the administrative boundary of Bogotá. It is part of the southern west area of the Bogotá River floodplain which was gradually reclaimed for housing uses. The interest to formally develop this area for housing dates back to 1953, when the municipality of Bosa was annexed to Bogotá. The first informal neighborhoods appeared as a result of the subdivision of agricultural estates, draining the land with rudimentary canals and building on low quality fillings from waste construction materials. These strategies did not provide any protection against frequent floods. Several studies for the Bogotá River flood control and environmental recovery developed between 1963 and 1988 studied drainage alternatives for these low lands. Not much of these plans was implemented, except emergency works between 1979 and 1981 that responded to the severe flood of 1979.

By 1991, EAAB formulated the project Santafe I. The project had two main objectives. One was to reduce flooding. The other was the construction of sewer networks in the periphery to enable the construction of large social housing projects (Hidroestudios, 1999). The water infrastructure works began in 2000, guided by a water management plan for the El Tintal watershed. This included the construction of the Canal Cundinamarca, a long canal parallel to the Bogotá River that collects rainwater from perpendicular canals and wastewater from new sewerage interceptors. The same year the area was officially included in the Bogotá's POT (land use plan). After the construction of the Canal Cundimarca the area became the largest container of Social Housing projects, among them the EI Recreo and EI Porvenir and other private developments.

At the moment the most southern area, which is still undeveloped, it is not covered by the water infrastructure. The area is undergoing a huge pressure due to the proximity to legalized neighborhoods and areas of emerging subdivision. There are two partial plans (urban development plans) proposed in the area: Campo Verde and El Eden. The implementation of both is facing difficulties. Campo Verde mainly due to flood risks (Maldonado, 2016; Pava, 2016) and El Eden because the Indian community of the "Cabildo Musica de Bosa"., that owns 
part of the land, was not included during the formulation of the plan. In addition, part of the land was declared as ecological structure in the Bogotá's POT of 2000.

\subsection{Design task}

The confluence of the Bogotá and Tunjuelo Rivers suffers from seasonal river overflows and water pooling due to the low level of the land. New studies to update the flood prone areas will be developed when the construction of the project "Bogotá River environmental restoration and hydraulic control" is finished (POT, 2013). There are three options for the area: (a) To keep the land agricultural. However, the agricultural activities had decreased and informal settlements are being emerging. (b) To developed the land following the existing master plans. These plans were design depending on traditional hard engineered solutions for water management and left little room for indeterminacy. (c) To develop the area providing space for water, protecting exiting settlements and integrating the environmental protection areas. This design investigation aims to develop the last option by applying the above-mentioned design strategies (See 2.1).

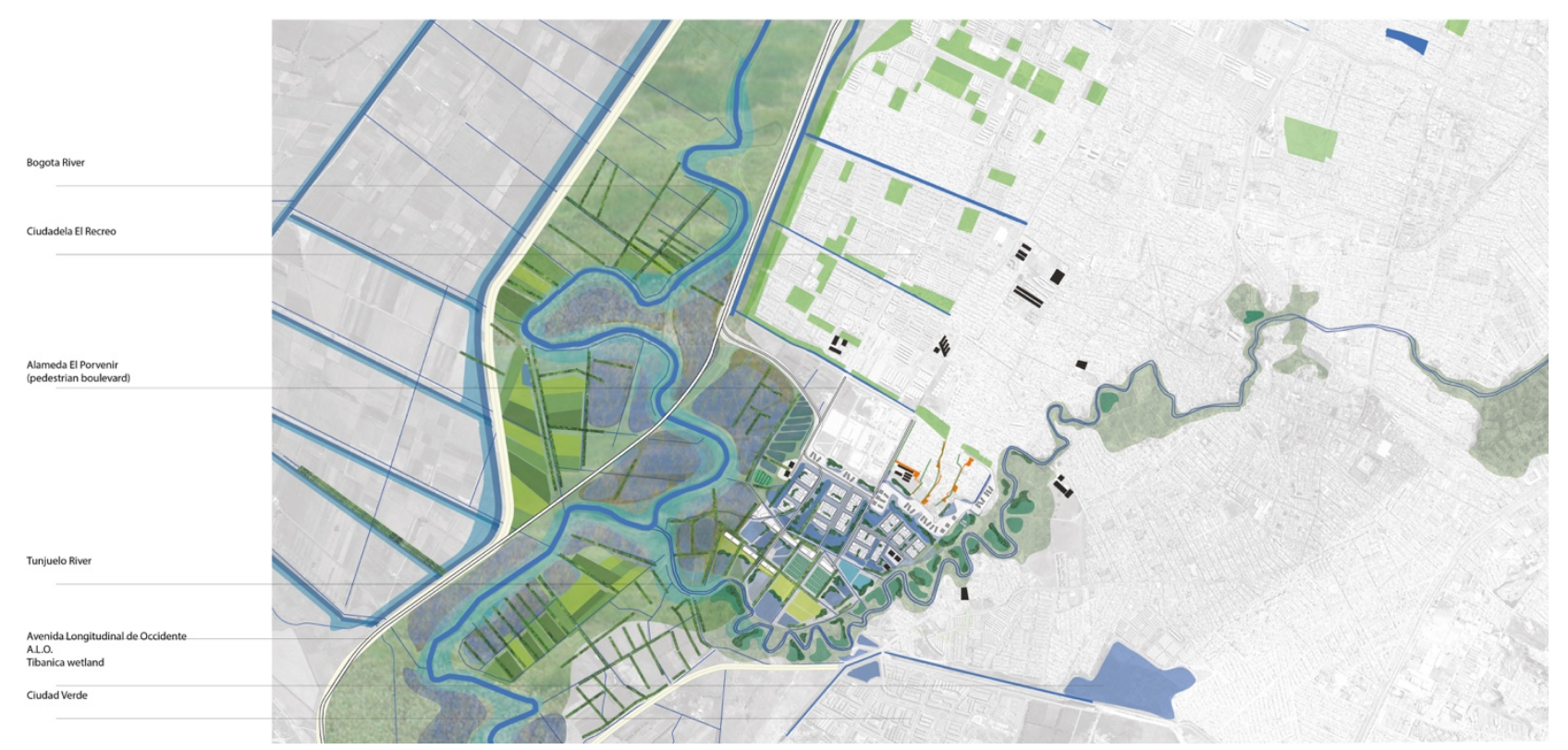

Fig. 4. Design investigation in section 1: Bosa.

Elaborated by the author.

\subsection{Topographical manipulations}

The principle of topographical manipulation strategy attempts to provide more space for water and at the same time strength different landscape and urban conditions of the site. The new topography creates three distinctive landscapes: (1) The new multifunctional dyke that serves as a threshold between the existing and the new tissue. (2) Elevated urban islands that create safe levels for housing and infrastructure. (3) A floodable research park by transforming the underused agricultural areas into water detention ponds.

The new paradigm in water management appeals for a "soft engineering" approach that manipulates the existing layer of water infrastructure according to natural processes and urban dynamics as well new ways to anchor development to this hybrid infrastructural system (De Meulder \& Shannon, 2010). The continuous heightening and strengthening of the dykes created a physical barrier that disrupts spatial continuity and reduce the rivers and their ecologies to a narrow strip. However, dikes have powerful design potential (Prominski, 2012). Instead of being a continuous line, the proposed dike is designed as a green infrastructure that bifurcates and interweaves with the urban fabric the road infrastructure. The dike can be couple with other programs by varying its width. Part of the dike can be converted in the proposed highway Avenida Longitudinal de Occidente A.L.O, other parts can serve as a platform for social housing or social infrastructure. The geometry of the new dyke follows the main lines of the existing plots. It protects existing settlement from floods and at the same time it is a landscape of integration that gives space for the confluence. The dike serves a platform and provides visual and physical connectivity toward the new water landscapes. 

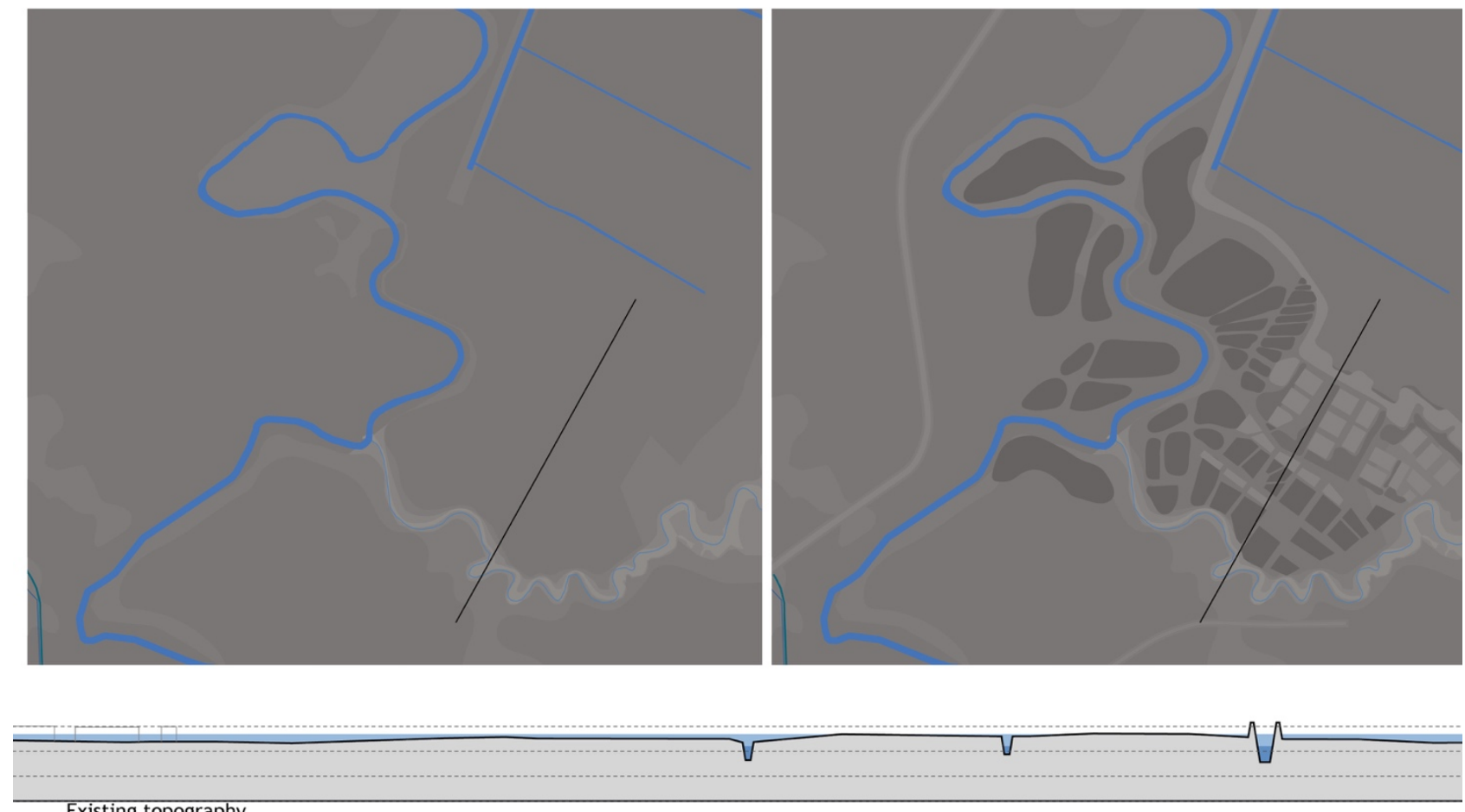

Existing topography

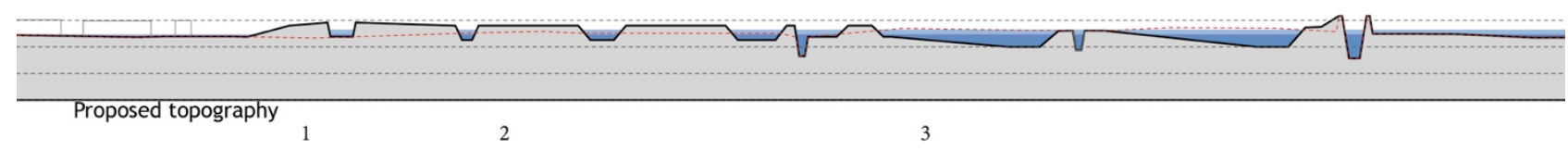

Fig. 5. Existing topography (left) Proposed manipulated topography (right) Elaborated by the author.
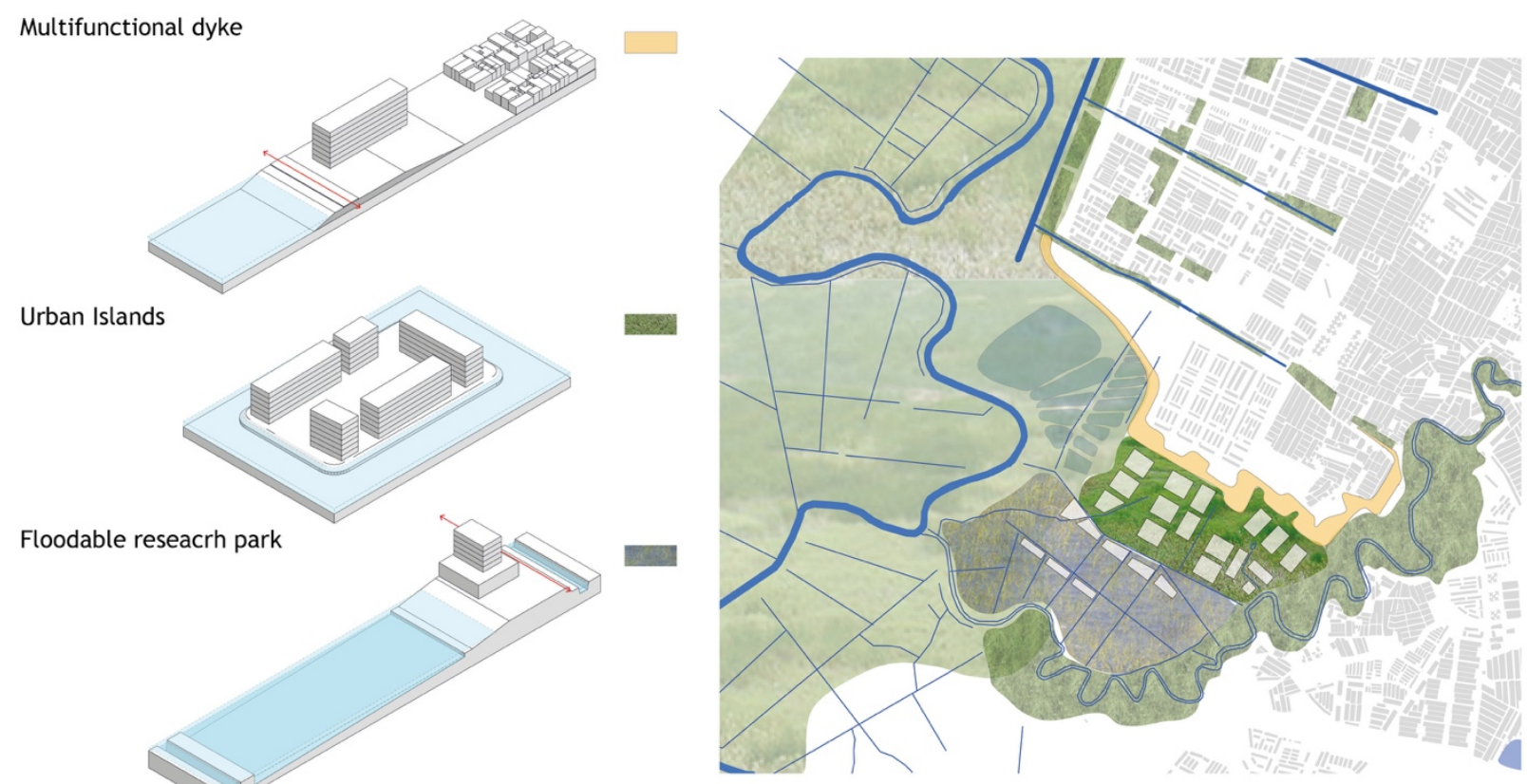

Fig. 6. Landscape typologies.

Elaborated by the author. 


\subsection{From water lines to water fields}

One of the most effective strategies to increase resilience is to provide space for water (Prominski, 2012; Shannon \& De Meulder, 2013). The possible strategies to provide space for water retention include (a) To recover the floodplain of the river and the associated ecologies at the river edge. (b) To expand the water retention capacity of existing water elements. For instance, transforming the section of existing irrigation canals, changing under-used agricultural areas into wetlands. (c) To integrate spaces for storm water collection within the new and the existing urban tissue.Creating space for water not only reduces the dependence on traditional engineered systems but also improves ecological performance as water flow nourishes a range of plant and animal species. It also creates a tangible link between people and climate change. "Water is political, not only in moments of scarcity but also in moments of abundance" (Picon, 2015: 37). By making visible the relation with water design can make visible its value as environmental and civic common space (Orf, 2016).

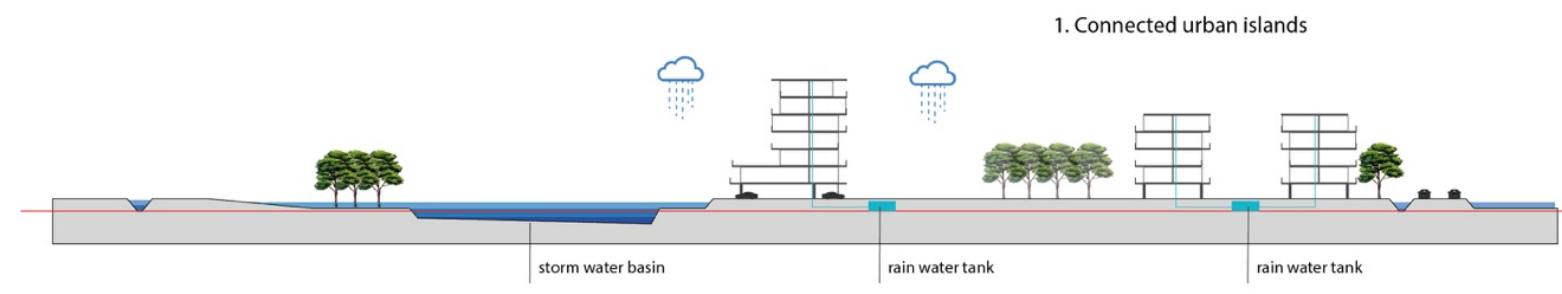

2. Self-built neighborhood

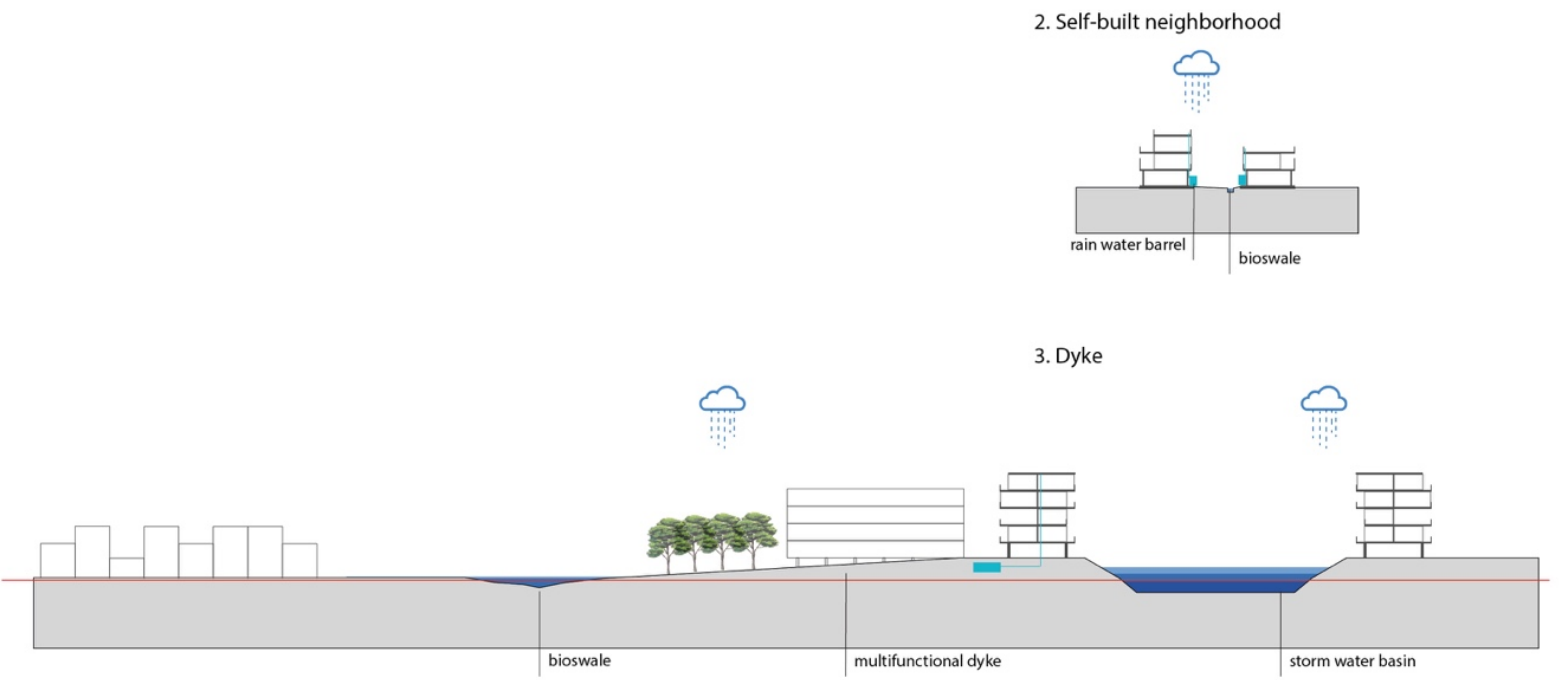

Fig. 7. Strategies for integrating storm water management within the urban tissue.

Elaborated by the author.

\subsection{Floodplain re-programming}

Originally the confluence was a marshland. Currently, there are agricultural activities but it is defined by the land use plan as part of Bogotá's ecological structure. The area is at the edge between urban and rural landscapes, will have good connectivity once the project for the ALO is constructed and the proposed manipulation of the topography will create new areas where water levels fluctuate. This could be an opportunity to create a new type of productive and research park for Bogotá, on which different uses for the ponds and wetlands can be explored. Research activities could include, water treatment technologies, fish farming, hydroponics and solar energy. Research can also include the recuperation of the indigenous ridge fields. Traces of some of them are still visible in the proximity to the Bogotá River and can provide an opportunity to respond to the demands from the Indian community and at the same being an important archeological landmark along the river course.

Investment in agricultural research is one of the key components of the recently signed agreement between the government and the FARC. The investment in the implementation of this agreement can be canalized towards the realization of the research park. More importantly the outcomes of the research can be multiplied on other areas of the Sabana. 
At the same time these activities can be combined with recreational uses, like camping or fish farming. This research park would be articulated with the extended Alameda El Porvenir, a boulevard street of $18 \mathrm{~km}$ that forms a civic axes and structuring element of the neighborhoods at the east of the Bogotá river. Traditionally, non-formal activities, like farming and animal husbandry have been excluded from the formal city. This park could be also an opportunity to provide alternative programs for rural immigrants and internal displaced people providing a landscape of integration between the city and the Sabana and between the rural immigrants and their new environment.

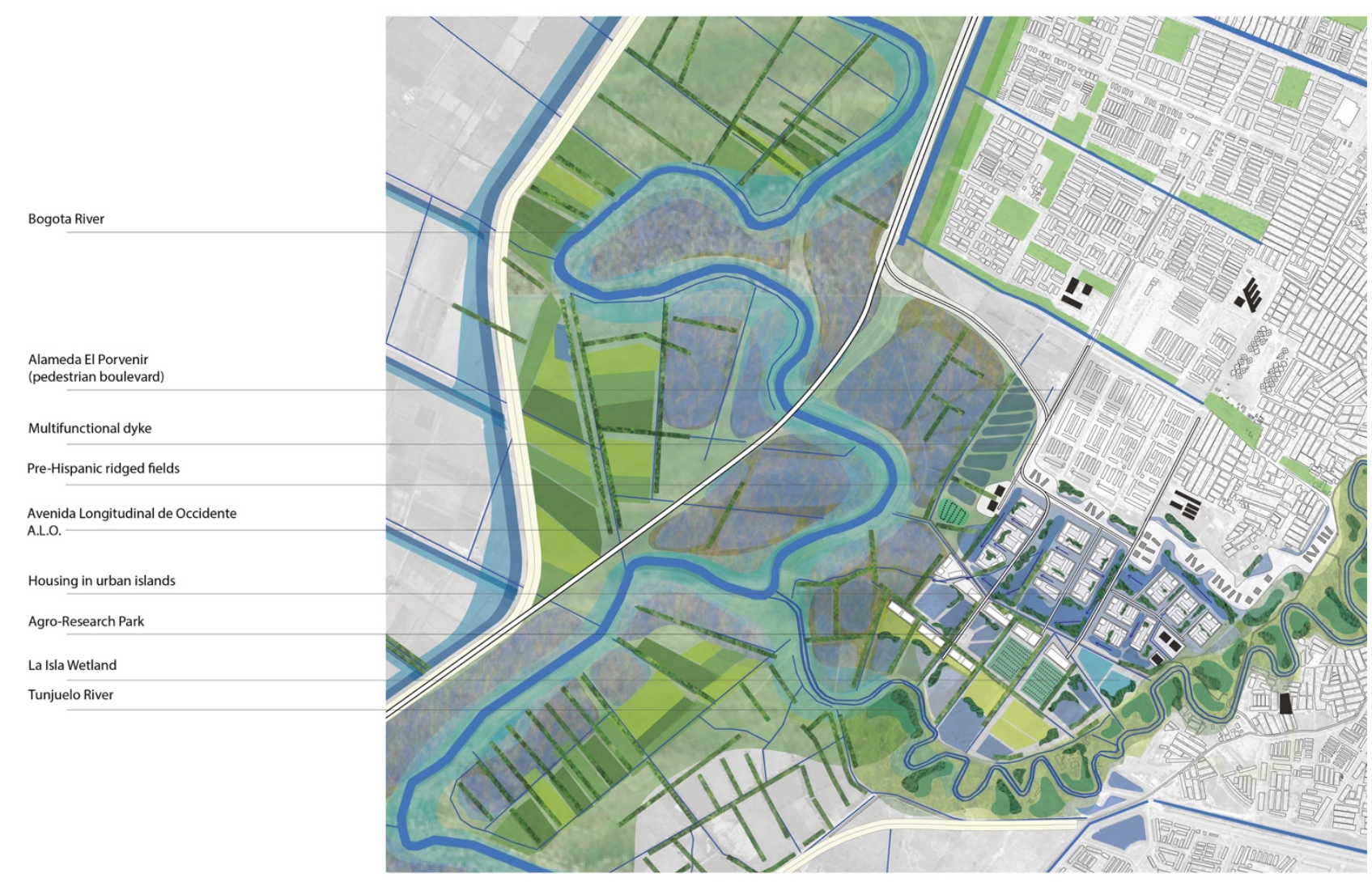

Fig. 8. Zoom of the design.

Elaborated by the author.

\section{SECTION II. FUNZA AND MOSQUERA}

The section cuts through the middle area of the Sabana de Bogotá, including the Guali wetland and the municipalities of Funza and Mosquera. The urban growth of these municipalities exemplifies urbanization trends in the Sabana de Bogotá. Today, unplanned growth is in conflict with the agricultural identity of the landscape which comes from the very fertile soils and centuries of development of irrigation networks. During the pre-Hispanic period land productivity depended on the natural river cycles and water management was well-suited to the wetlands and the floodplains (Rojas; De Meulder \& Shannon, 2015). After the seventieth century, land was progressively reclaimed for agriculture and livestock through the superimposition of a network of ditches. This network was gradually improved and later transformed in the irrigation district La Ramada that provide fresh water supply from the Bogotá River during the dry season and drainage during the rainy season. The fast development of housing and industry after the 1990s is rapidly transforming the water system. Canals are being filled and wetlands encroached while agriculture is abandoned due to land speculation and water scarcity.

In the municipalities of Funza and Mosquera land is cheaper and legal procedures are faster and easier for urban developers. These conditions have facilitated social housing production. For instance, 14,517 social housing units were constructed between 2002 and 2007. This growth was not predicted during the development of their respective urban plans. Municipal regulations do not require the provision of social infrastructure (schools, healthcare and recreation facilities) within the housing projects, rapidly outpacing the capacity of existing social infrastructure (Escallón, 2010). 
The main landscape element is the Gualí- Tres Esquinas wetland, which is one of the few environments that preserve some original characteristics of wetlands ecosystems in the Sabana de Bogotá. Its conservation is critical for the overall hydrological performance of the Bogotá River floodplain and for environmental conservation in the region. In addition, the wetland functions as a reservoir for La Ramada irrigation district.

\subsection{Design task}

Population projections estimate the need to construct 58,000 new housing units by 2030 (DANE, 2006). These projections ignore the regional population dynamics, especially from Bogotá. The population growth will increase the pressure in the Gualí-Tres Esquinas wetland and water stress in the whole region. In order to preserve and restore the wetland, the Corporación Autonóma Regional de Cundinamarca CAR, declared it as a protected area "Distrito Regional de Manejo Integrado" (DMI) in February of 2014 (Acuerdo 001 de 2014). This legal framework is an initial step towards the ecosystem restoration, but it is restricted to the wetland and its immediate surroundings. In addition, it is unclear how this statute can be translated in spatial interventions for the preservation of the wetland that at the same time respond to the urban dynamics and economic needs.

This design investigates the potential of the water structure to simultaneously deliver the frame in which new housing fabrics can be integrated while preserving and restoring the productive and environmental qualities of the landscape.

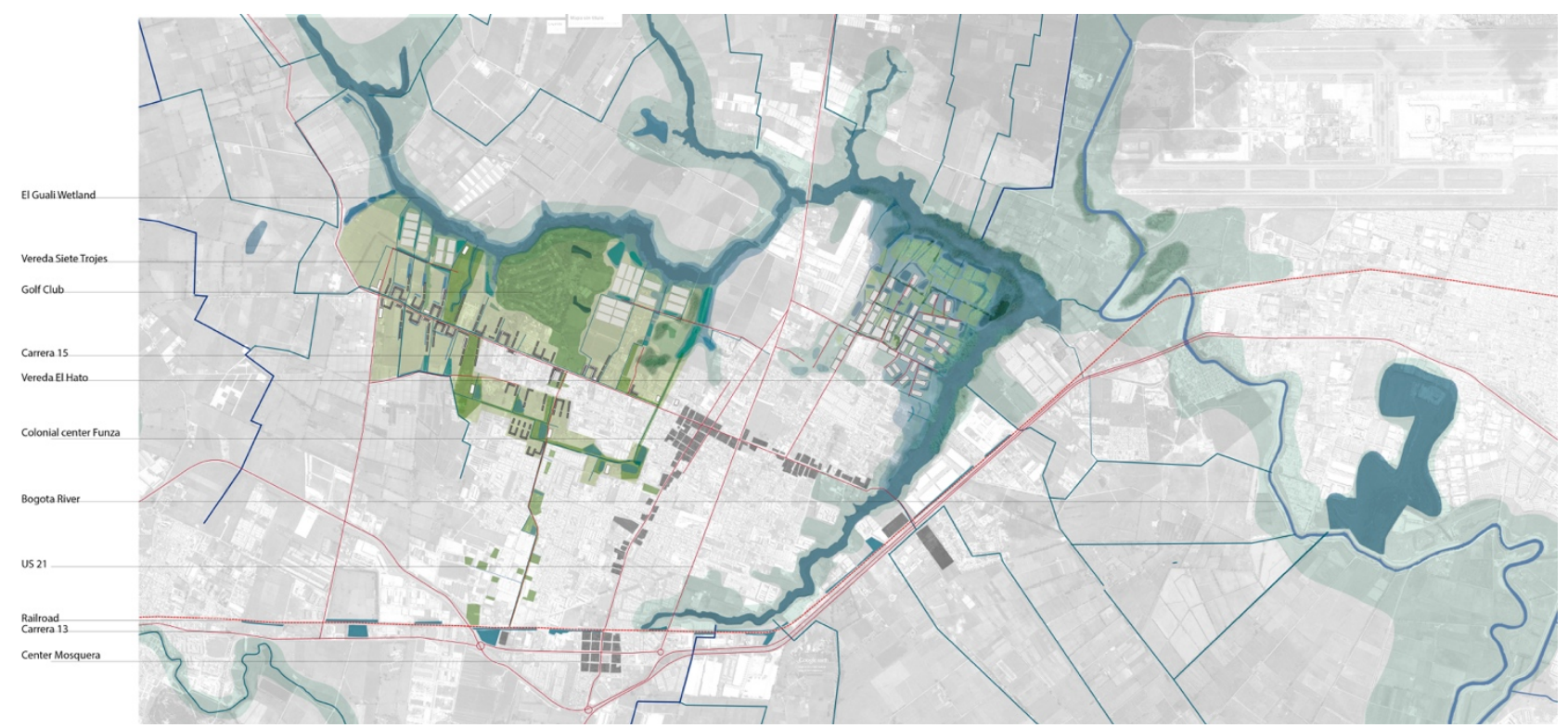

Fig. 9. Design investigation in section 2: Funza and Mosquera.

Elaborated by the author.

\subsection{Sites: Vereda El hato and Vereda Siete Trojes}

The vereda El Hato is located in the eastern part of Funza. It is the lowest land in proximity to the Gualí-Tres Esquinas wetland. The vereda can be divided in two areas. An agricultural area divided in large plots of land and the urban area of Funza divided in small plots on which informal housing started to develop since 1970s. During the pre-Hispanic period, the main large Indian Muisca settlement was likely located closed to this area (Boada, 2013). After Spanish conquest, the land was used almost exclusively for agriculture. In 2005, the first industries were constructed along the regional road US 21. New housing projects are constantly pushing the boundaries of the urban land.

The Vereda Siete Trojes is located in the north part of Funza and Mosquera. Originally rural areas covered a large territory that was fragmented due to the development of industrial parks, flower farming and housing. During the 1960s the area was inhabited by families dedicated to medium scale agriculture. Some of this medium -scale farms preserved the agricultural tradition until the end of the 1980s. Today few peasant families are still present. They own small plots of land (less than one hectare). The disappearance of agriculture is strongly related to the transformation of the water system as a result of urban development. 


\subsection{Topographical manipulations}

The same principle of topographical manipulations used in section I: Bosa is replicated in this section. In the vereda El Hato, the ongoing housing and industrial projects are built by raising the land 1 to $1.5 \mathrm{~m}$. There is also a dyke of about $2 \mathrm{~m}$ in some sections of the wetland. The proposal rationalizes these existing processes. The structure of the large plots is preserved as a major framework on which topography is manipulated to create safe areas for housing. The design attempts to create a dynamic gradient of wet and dry as interface between the wetland and the city. The new housing typologies are choreographed to dissolve within the preserved wetland.

In the vereda Siete Trojes, new platforms for housing are created taking advantage of the natural topography that is higher along the Carrera 15 (main road) and lower towards the wetlands. Cut and fill strategies define three areas and give more space to water. One along the main street that connects with the colonial center. Here the typologies create a civic axis with commercial activities, social facilities and a series of open/public spaces. An intermediate zone that combines high density housing with agriculture. And a lower area for the extension and preservation of the wetland in which flower is combined with ponds for rain water collection.
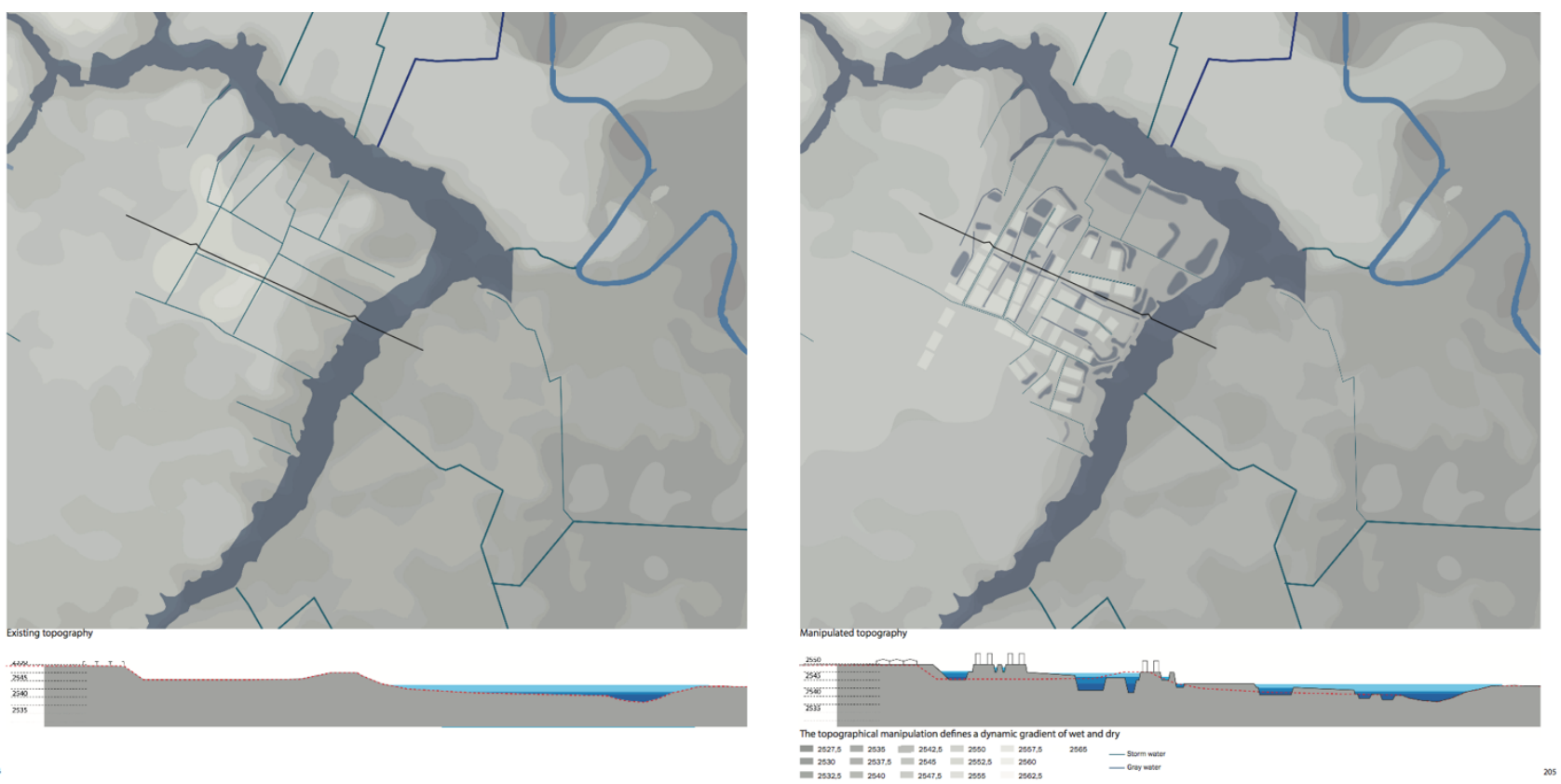

Fig. 10. Topographical manipulation in the Vereda El Hato. Existing (left) Proposed (right) Elaborated by the author.

\subsection{Reconfiguring the water cycle and recovering productivity}

Every year Funza receives an average rainfall of $600 \mathrm{~mm}$. Since the soils here are mostly impermeable most of this rainfall is lost. At the same time, the aquifers are being pumped out and the water table is descending quickly. The growing demands for fresh water, the effects of climate in the reduction of the paramos ecosystem and the changes in rainfall patterns, worsened by "el niño" effect, make necessary to introduce a system of storm water collection and gray water recycle and re-use.

There are some families that still preserve the agriculture traditions. Especially in the vereda Siete Trojes. They planted small orchards in their plots on which they grow tree tomato, vegetables, herbs, potatoes, corn. However, these activities are not their main economic resource. Family members work in the industrial sector, in the flower farming industry or in tertiary activities. Due to water shortage, they are facing more problems to preserve the rural life style as well as pressure from development to sell their plots.

The preservation of the agriculture identity has a potential role in "determining the economic, ecological and spatial order of the city" (Waldheim, 2010). The irrigation system, built after 1920, is critical to guarantee food security for the region. The design manipulates this layer, integrating a new agricultural order that simultaneously functions as a structural framework for housing. The proposed gray-water system is organized as an independent series of decentralized units. In each of them gray water from the housing blocks is cleaned through a sequence of wetlands. Agricultural plots are arranged to benefit from the treated gray water, 
preserving the existing land sub-division. Storm water run-off is integrated in the street profiles, cleaned through linear swales and directed also to the agricultural plots or wetlands. Recently, flower farming industry started to collect the storm water in order to obtain international certification in sustainable practices. Integrated systems of harvesting rain water can also be incorporated to the design of the social housing blocks.

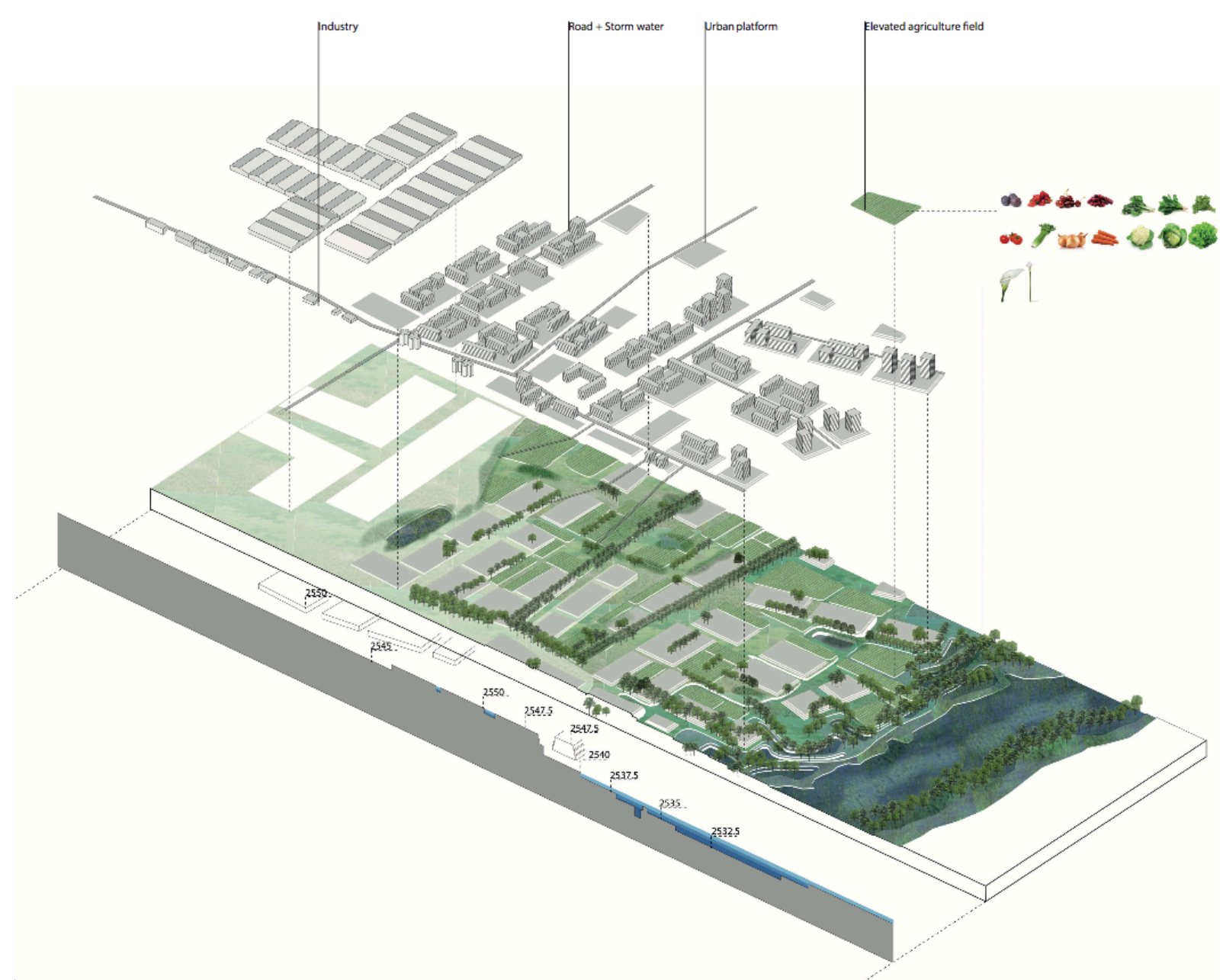

Fig. 11. Sectional design in the vereda El Hato.

Elaborated by the author.

\subsection{Polytechnic water infrastructure}

Modern water management prioritize a "monotechnic" technology for the sake of technology progressively eliminating biological diversity and socio-cultural uses. This approach was question under the paradigm shift of sustainable water management that advocates for the return of a "polytechnic" approach that provides a complex framework to solve human and environmental needs. The proposal provides a framework for the urban blocks that is defined by topography and water flows. The sectional design combines the re-engineered of the water system with landscape programs. Street profiles are designed as boulevards and integrate storm water management. Water treatment ponds can be used as ecological devices and recreational activities. Agricultural areas could be temporarily flooded in order to cope with major extreme events.

The original extension of the wetland was reduced by filling some branches and other areas were canalized. The existing tissue is composed by a patchwork of tissues that left vacant plots scattered inside the urban area but without a clear structure. The new water structure is proposed as functional network but at the same time as a public armature that connects the existing tissue with the main landscape elements. 


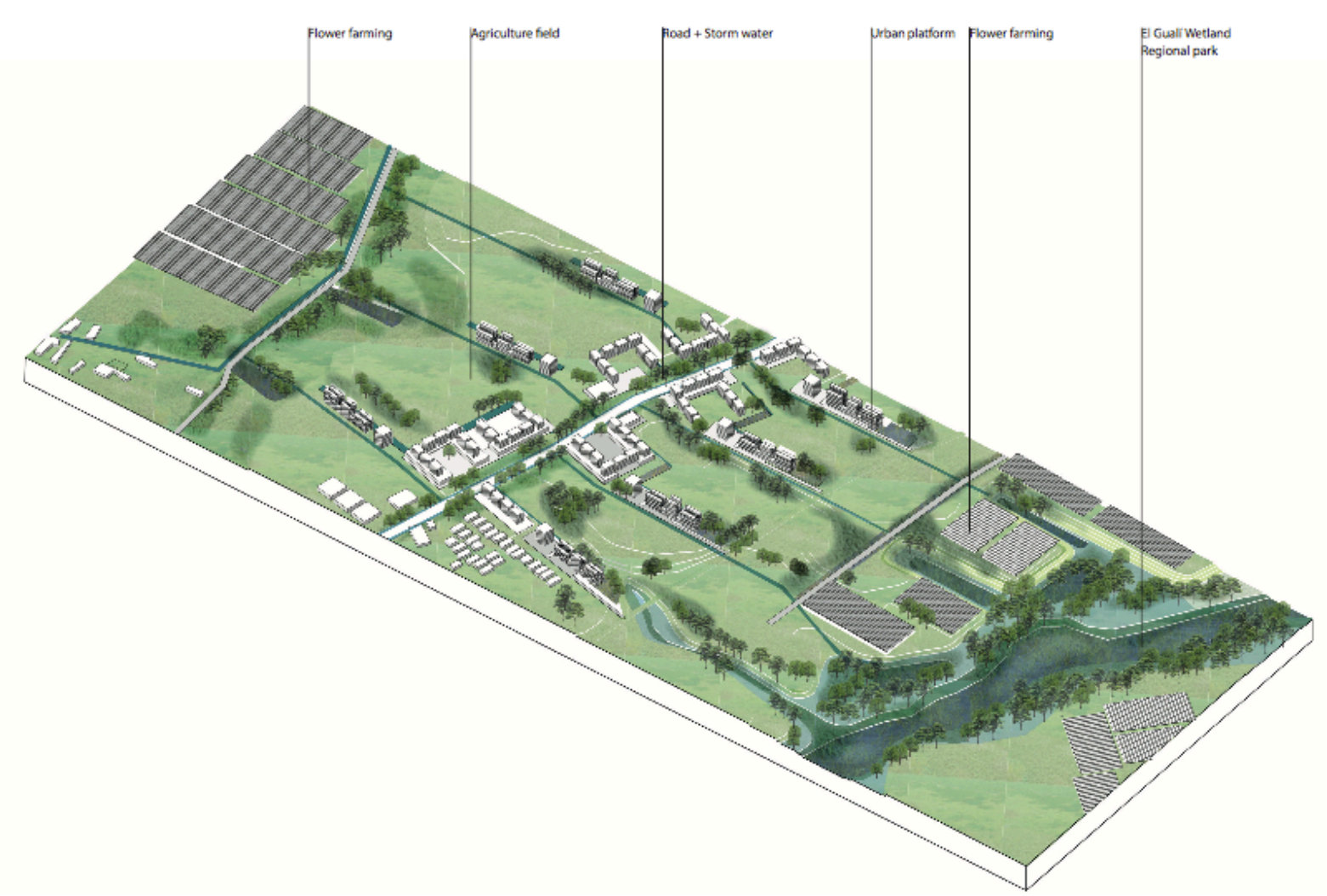

Fig. 12. Sectional design in the vereda Siete Trojes. Elaborated by the author.

\subsection{Open housing tissue and urban armatures}

Elevated plots are distributed according to the existing topography and the water flows. The plots cluster along the main infrastructural lines given continuity to the urban tissue and creating a civic axis that contains commercial functions and services. The occupation of the land decreases towards the wetland while density increases taking advantage of the view over the natural surroundings.

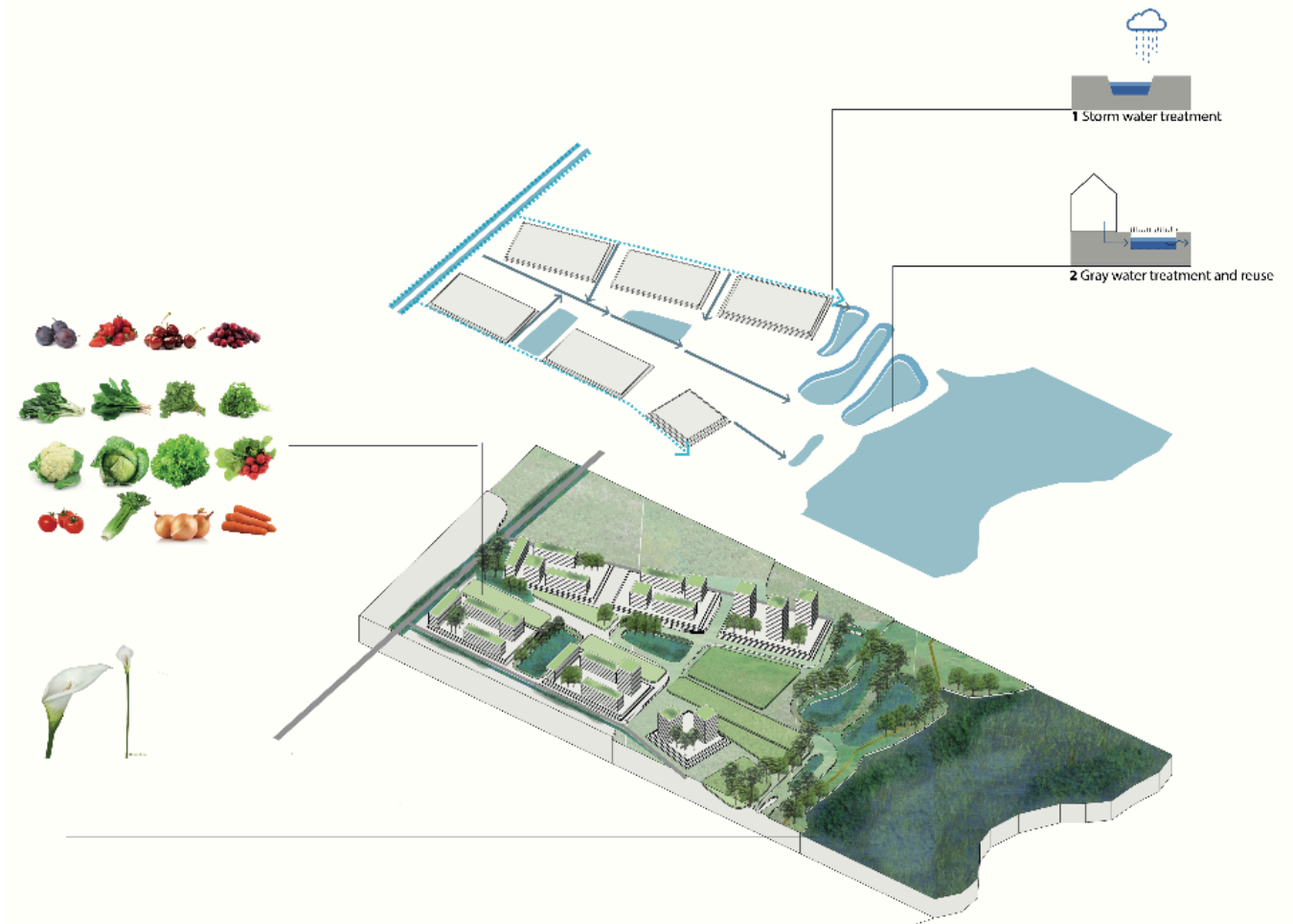

Fig. 13. A decentralized unit of water management.

Elaborated by the author 


\section{Conclusion}

The research proposes a landscape urbanism approach to deal with the contradiction between the provision of social housing and environmental protection in the Sabana de Bogotá. It attempts to contribute to the debate of how the city should grow by developing hybrid strategies that work with the forces of nature. It challenges the rooted perception of the contradiction between the city and the "natural" Sabana and replace by the reading and projection of an urban figure diluted into the productive landscape. Water and soil are the main natural resources in the Sabana. It is already clear that the main issues regarding the future sustainability of the region are the supply of potable water and social housing. Productive and economic activities need to be reconsidered and the agricultural identity need to be preserved. This is especially clear when we consider that expanding world population is leading to a food crisis and local food production as an important factor for ecological sustainability, biodiversity and environmental health. In addition, there is a need for an overall strategy social housing provision that considers the particular conditions of the territory. The ecology of the Bogotá River is related to the natural fragile ecosystems as much as it is to the infrastructure networks that redistribute water. However, today the river is a dead water body. To return the river to a "natural" state is a naïve objective. Design has a crucial role in developing hybrid assemblages that respond to the contradictory challenges embedded in the landscape of the Sabana. In order to test this approach, this paper presented design investigations that explore the structuring capacity of the water network. These design investigations allow to identify three key elements that can be the base for developing a constructive interplay between water and settlement in Bogotá and also elucidate the application of landscape urbanism principles in contexts of rapid development:

Site Specificity: Design investigations started by understanding the natural and socio-economic conditions of the site. In order to increase landscape resilience in the Sabana de Bogotá urban tissues should recreate the original field condition as a "sponge". The landscape typologies developed in this paper illustrate how this condition can be restore in different sites by creating an open tissue that is intertwined with the hydrological infrastructure and productive landscapes.

Double coding: Design strategies were defined to address multiple issues simultaneously. In the case of the Sabana de Bogotá de hydrological infrastructure creates a framework to solve housing needs while improving the environmental conditions. The design started by de-constructing the complex water system. The water network is a support for the spatial structure, but it is partly hidden. However, when it is visible it creates conflicts with the public sphere due to pollution. The potential to transform this water network can be explored by understanding its physical relation with the built environment as well as the way in which water is metabolized by the city. The new relations between water and settlement proposed by the design are based on the specific characteristics of the water network and the different layers that composed it. The traces of indigenous field, the irrigation and storm water canals, the wetlands, and the defensive elements like dykes. Each of these layers have their own logic and their potential depend on the relation with the topography and with the water cycle. Once the water network is transformed into a visible structuring element it allows to make evident process and cycles creating awareness in the population. The interrelations constructed along the new water system also hold the potential of supporting new economies that are closely tied to existing activities and landscape logics.

\section{Sectional representation:}

The design investigations are always at the intersection between the reading of the site and its logics and the potential to intervene and transform existing structures. Addressing issues of climate change and integrated water management requires to find new design tools. During the development of the design investigations sectional design played a crucial role. As an interpretative tool, sections allow to integrate different types of knowledge and to highlight the interconnectedness between different systems which enabled a deeper understanding of the site. As a projective tool, sections settle a terrain in which development can occur and also organize new relations between different uses and programs that close the water cycle.

The design investigations elaborated new alternatives regarding the urban conditions of the housing production, in order to preserve fragile ecologies, create qualitative public infrastructure, guaranty a more sustainable use of water and create new relations with existing economies. More research has to be done regarding the quality of the dwelling units and the funding schemes for housing production. 


\section{BIBLIOGRAPHY}

BOADA, A. M. (2013). From small household clusters to the central place of the Bogotá chiefdom. In S. Palumbo, A. M. BOADA, W. LOCASCION, \& A. MENZIES (Eds.), Multiscalar Approaches to Studying Social Organization and Change in the Isthmo-Colombian Area (39-70). Bogotá: Universidad de los Andes/Center for Comparative Archaeology.

CABALLERO, Y., \& AMAYA, F. (2014). Ciudadela El Recreo en Bogotá: procesos, planificación y vivienda. In T. GARZON (Ed.), Vivienda para pueblos indígenas en ciudades capitales andinas (pp. 191-212). Quito: ONU-Habitat.

CATOOR, B., \& DE MEULDER, B. (2010). Iteration between Collaborative Urbanism and Formal Cartographies. Design experiments in Southwest Flanders. In N. MEIJSMANS (Ed.), Designing for a Region (202-213). Amsterdam: Sun.

CORNER, J. (1999). The Agency of Mapping: Speculation, Critique and Invention. In D. COSGROVE (Ed.), Mappings (211-252). London: Reaktion books.

CODHES. (2008). Codhes Informa. Tapando el sol con las manos. Informe sobre el desplazamiento forzado, conflicto armando y derechos humanos, enero-junio de 2008. Boletín Informativo de la Consultoría para los Derechos Humanos y el Desplazamiento, número 74, Bogotá, 25 de. Retrieved from www.codhes.org

DE MEULDER, B., \& SHANNON, K. (2010). Traditions of Landscape Urbanism. Topos, (71), 69-73.

ESCALLÓN, C. (2010). Las preguntas por la calidad de la vivienda: ¿quién las hace?, ¿quién las responde? Dearq, (6), 6-19. Retrieved from http://dearq.uniandes.edu.co/sites/default/files/articles/attachments/dearq06_01_-_Escallon_-_Rodriguez.pdf

HIDROESTUDIOS S.A. (1999). Diseños detallados para el sistema troncal de alcantarillado sanitario y pluvial de la cuenca del Tintal en Santafé de Bogotá (Vol. 4). Empresa de acueducto y alcantarillado de Bogotá-ESP.

HIGHT, C. (2014). Designing Ecologies. In C. REED \& N.-M. LISTER (Eds.), Projective ecologies (pp. 84105). New York: Actar.

GILBERT, A. (2009). The rise (and fall?) of a state land bank. Habitat International, 33(4), 425-435.

https://doi.org/10.1016/j.habitatint.2009.01.003

METROVIVIENDA. (2011). Una Reflexión Sobre la Producción de Vivienda Social en Bogotá 1998 - 2010. Bogotá: Buenos y Creativos S.

NOLF, C., \& DE MEULDER, B. (2013). From planning to profiling: reactivating characteristic watermarks to structure the Flemish territory. Journal of Landscape Architecture, 8(2), 37-41.

https://doi.org/10.1080/18626033.2013.864123

NOVOTNY, V. (2008). Sustainable urban water management. In J. FEYEN, K. SHANNON, \& M. NEVILLE (Eds.), Water and urban development paradigms (19-31). London: Taylor \& Francis Group.

ORFF, K. (2016). Toward an urban ecology. New York: The Monacelli Press.

PALMBOOM, F. (2010). Drawing the ground - landscape urbanism today: the work of Palmbout Urban Landscapes. Berlin: de Gruyter.

PICON, A. (2015). Water, Technology, and Society: A Historical Overview. In L. MARGOLIS \& A. CHAOUIN (Eds.), Out of Water - Design Solutions for Arid Regions (29-39). Basel: Birkhäuser. 
POT Plan de ordenamiento territorial. Decreto 364 de 226 de 2013 (2013). Bogotá: Alcaldía Mayor de Bogotá.

PROMINSKI, M. (2012). River, space, design: planning strategies, methods and projects for urban streams. Basel: Birkhäuser.

PROMINSKI, M. (2016). Research and design in JoLA. Journal of Landscape Architecture, 11(2), 26-29. https://doi.org/10.1080/18626033.2016.1188565

REED, C., \& LISTER, N.-M. (2014). Parallel Genealogies. In C. REED \& N.-M. LISTER (Eds.), Projective ecologies (pp. 22-39). New York: Actar.

ROJAS, C., DE MEULDER, B., \& SHANNON, K. (2015). Water urbanism in Bogotá. Exploring the potentials of an interplay between settlement patterns and water management. Habitat International, 48, 177-187. http://doi.org/10.1016/j.habitatint.2015.03.017

SECRETARIA DE PLANEACION. (2009). Proyecciones de poblacion e indicadores demograficos de Bogotá.

SHANNON, K. (2004). Rhetorics and Realities Addressing Landscape Urbanism. Three Cities in Vietnam. University of Leuven.

SHANNON, K. (2008). The "agency of mapping" in South Asia: Galle-Matara (Sri Lanka), Mumbai (India) and Khulna (Bangladesh). Footprint, (2), 105-119.

SHANNON, K., \& DE MEULDER, B. (2013). Water Urbanisms 2 - East (UFO: Explorations of Urbanism. Zurich: Park Books.

SHANNON, K., \& MANAWADU, S. (2007). Indigenous landscape urbanism: Sri Lanka's reservoir \& tank system. Journal of Landscape Architecture, (Autum 2007), 6-17.

SHANNON, K. (2016). Amid shifting paradigms: teaching and research. Journal of Landscape Architecture, 11(2), 84-89. https://doi.org/10.1080/18626033.2016.1188577

TORRES, C. (2011). Producción y transformación del espacio residencial de la población de bajos ingresos en Bogotá en el marco de las políticas neoliberales (1990-2010). Universidad de Valladolid.

TARCHOPULOS, D. (2003). Vivienda social: miradas actuales a retos recientes. Bogotá: Pontificia Universidad Javeriana.

WALDHEIM, C. (2010). Notes toward a history of Agrarian urbanism. Places. Retrieved from https://placesjournal.org/article/history-of-agrarian-urbanism/

Electronic sources

EL TIEMPO. (2016, February 27). Metrovivienda será banco de suelos para vivienda masiva. Retrieved from http://www.eltiempo.com/bogota/metrovivienda-en-bogota/16521829

DANE. (2006). Censo General 2005. Retrieved from https://www.dane.gov.co/index.php/estadisticas-portema/demografia-y-poblacion/censo-general-2005-1

MALDONADO, M. (2016). ¿Recuerdan el proyecto Campo Verde en Bosa? Se construirá en contra de expresa orden judicial. Retrieved from http://imaginabogota.com/columna/recuerdan-el-proyecto-campoverde-en-bosa-se-construira-en-contra-de-una-orden-judicial/ 
PAVA, J. (2016). En el proyecto Campo Verde Peñalosa expone a riesgo de inundación a más de 6.129 familias de bajos recursos. Retrieved from http://imaginabogota.com/columna/campo-verde-penalosaexpone-inundacion/

SECRETARIA DISTRITAL DEL HABITAT. (2015). Encuesta Multiproposito 2014. Retrieved from http://www.sdp.gov.co/portal/page/portal/PortalSDP/Encuesta_Multiproposito_2014/CartillaMultiproposito.pdf 